Check for updates

London, UK

Cite this as: BMJ 2020;371:m4330 http://dx.doi.org/10.1136/bmj.m4330 Published: 9 November 2020

\section{Covid-19: NHS England should manage test and trace system, says Independent SAGE}

\author{
Shaun Griffin
}

The Independent Scientific Advisory Group for Emergencies (Independent SAGE) has renewed its call for urgent reform of the government's covid-19 test and trace system, ${ }^{1}$ urging that it be replaced by a system overseen by the NHS to avoid future lockdowns.

Independent SAGE showed that 1217214 contacts have been reached by England's NHS Test and Trace service since May at an approximate cost of £10 ooo ( $€ 11$ 000; \$13 000) per head so far, based on the government's commitment to spend £12bn on a tracking system. Contact tracing in the national service is provided by the private companies Serco and Sitel.

Latest figures show that the number of contacts traced has remained stagnant at around 60\%. However, Kit Yates of the University of Bath concluded after analysing government data that only $14 \%$ of those who provided contacts have been reached and advised to quarantine. "We know that not everyone is isolating, because it's not practical for people and they're not being supported effectively," he said, projecting that only 5-10\% of those told to isolate are doing so.

Former chief scientific adviser David King said, "We need to get ourselves into the position where this is the last lockdown the country will go into, and in order to achieve that, we need an end strategy we know will work." He called for a "move away from the blunt instrument of lockdown into a focused instrument of finding, testing, tracing, isolating, and supporting all new cases within 24 hours."

He added, “The two key words are 'isolate' and 'support.' We don't believe that there's been anything like a focus on this. We need much better information on the people who are asked to isolate and how they are asked to isolate. All this needs to be conducted at a local level. The percentages are awful."

Commenting on the criticism of NHS Test and Trace, Gabriel Scally, visiting professor of public health at the University of Bath, said, "The state has been hollowed out since 2010 so there are no regional structures. A lot of what remains has been repurposed to commissioning and contracting, and not actually running things.” He said that only NHS England can make a test and trace system run properly. "They know what this pandemic is doing to the services they're trying to provide. Simon Stevens and the board of NHS England should step forward and say, 'you're not doing this properly, we'll take it on for the NHS and for the people of this country.'”

Anthony Costello of University College London called on the government to take four urgent steps over the lockdown period: provide proper compensation to people who isolate to improve compliance; change management of the Lighthouse Laboratories from the private sector to NHS molecular virology laboratories; shift "large amounts of money" into public health for local contact tracing; and establish an advisory panel that includes experts from the NHS and primary care.

Projecting forward from the latest Office for National Statistics data, Yates estimated that there had been 2500 deaths from covid-19 during this first week of the second national lockdown compared with 610 in the equivalent week in March. "The outlook isn't as bad now, but there's no room for complacency," he said.

\section{Universities and schools}

In order to prevent further spread of the virus, Independent SAGE called for universities to move immediately to online teaching and to allow students to return home to continue their studies to avoid large scale movement in December. Those returning home should be tested, or isolated if capacity doesn't allow, it added.

Zubaida Haque, commissioner at the Women’s Budget Group also noted the "deafening silence from government on the matter of ventilation, especially in classrooms and schools.”

\section{Correction: On 10 November we amended this story to make it clear that Serco is not the only private company involved in NHS Test and Trace and that the service covers more than just contact tracing.}

Wise J. Covid-19: Act now to avoid second lockdown, says Independent SAGE. BMJ 2020;370:m3695. doi: 10.1136/bmj.m3695 pmid: 32958513

This article is made freely available for use in accordance with BMJ's website terms and conditions for the duration of the covid-19 pandemic or until otherwise determined by BMJ. You may use, download and print the article for any lawful, non-commercial purpose (including text and data mining) provided that all copyright notices and trade marks are retained. 